\title{
MARKETING ACTIVITIES OF ENTITIES ON THE MILK MARKET AND SUSTAINABLE CONSUMPTION OF DAIRY PRODUCTS
}

Katarzyna Olszewska ${ }^{1}$, Anetta Waśniewska ${ }^{2}$, Ph. D.

${ }^{1}$ The State University of Applied Sciences in Elblag, ${ }^{2}$ Gdynia Maritime University

\begin{abstract}
In the conditions of the global milk market, which is focused on sustainable developement, the fundamental issues are the nutritional and social objectives combined with the marketing activities of the dairy market enterprises. In the market conditions significant changes may be noticed in consumer preferences in relation to products, their brands as well as market communication. Different forms of sales promotion are becoming more and more important. The result is high noticeability by consumers and a change in their purchasing decisions. Sales promotion plays an important role in balancing the dairy market and shaping desired consumer behaviour. For producers and suppliers, this means a necessity to choose the right range of products and different ways to reach consumers' awareness.

The aim of the research is to identify the key determinants that influence the consumer purchasing behaviour in the milk market and answer the question whether changes in consumers' attitudes give rise to particular implications for the marketing activities undertaken by today's entrepreneurs. The authors, basing on available reliable data generated for years 2010-2016, published by Central Statistical Office, EUROSTAT, Institute of Agricultural Economics and Food Economy and Agricultural Market Agency, identified the determinants relevant to the milk market in Poland. The years adopted for the analysis is a period of dynamic changes that took place in Poland. The set of milk market's determinants was defined in order to achieve the set goal. The variables were used for conducting examinations involving Hellwig's method to determine the value of the integral capacity of information carriers.
\end{abstract}

Key words: consumption, dairy products, marketing

JEL code: $\mathrm{C} 43$

\section{Introduction}

Changes in the realities of the global economy have caused the evolution not just in the production, technology or communication, but also in consumer processes that reflect the transformation of ideas and social attitudes. In terms of the global market, consumption has become a prerequisite for the functioning of economic systems (Mróz B., 2009). In the 21st century, excessive consumption leads to negative consequences not only for the economy as such, but also for the environment and society. The phenomenon can currently be observed in many countries: a waste of goods, of natural resources, of human work, environmental degradation or disparities between people. This situation has forced the emergence of new trends in consumption - greening or sustainable consumption that can be salvation for the balance of the world economy. The appearance on the market of organic and socially responsible products has become the implication for the marketing activities of modern enterprises and changes in consumer attitudes.

In the article, the authors try to identify the key determinants that influence the consumers' behaviour in the milk market and find the answer to the question whether changes in consumers' attitudes give rise to particular implications for marketing activities undertaken by the contemporary entrepreneurs. The importance of marketing activities and their impact on the volume of consumption is emphasized in literature. However, the authors of this article focused on available data for years 2010-2016 and, by means of the Hellwig's method, defined the determinants that have the greatest influence on the consumer purchasing behaviour in polish dairy market. 


\section{New trends in consumption}

T.Veblen, who is the creator of conspicuous theory of consumption, significantly contributed to the development of the theory of consumption. According to him the motive for turning to consumption of goods is not the need to survive but the desire to create the possibility of demonstrating differences between people. Possession of goods causes their owners to achieve higher status (Veblen T., 2008). According to J.Baudrillard, as the wealth grows and the level of consumption increases, new needs that over time acquire a cultural, social and moral contextand, as a result, move to the sphere of basic needs. This can be related to the image of an eternally insatiable consumer who is constantly looking for new consumer goods and sensations (Baudrillard J., 2006). In the second half of the 20th century, also postmodernism played an important role in the development of the trends of consumption, where the consumer is dynamic, mobile as well as creating new needs and looking for new sensations (Słaby T., 2006). Currently, changes in the consumption of highly developed societies do not have a unified direction and a multitude of options that are mutually exclusive or complementary can be observed. New trends in consumption are shown in Figure 1.

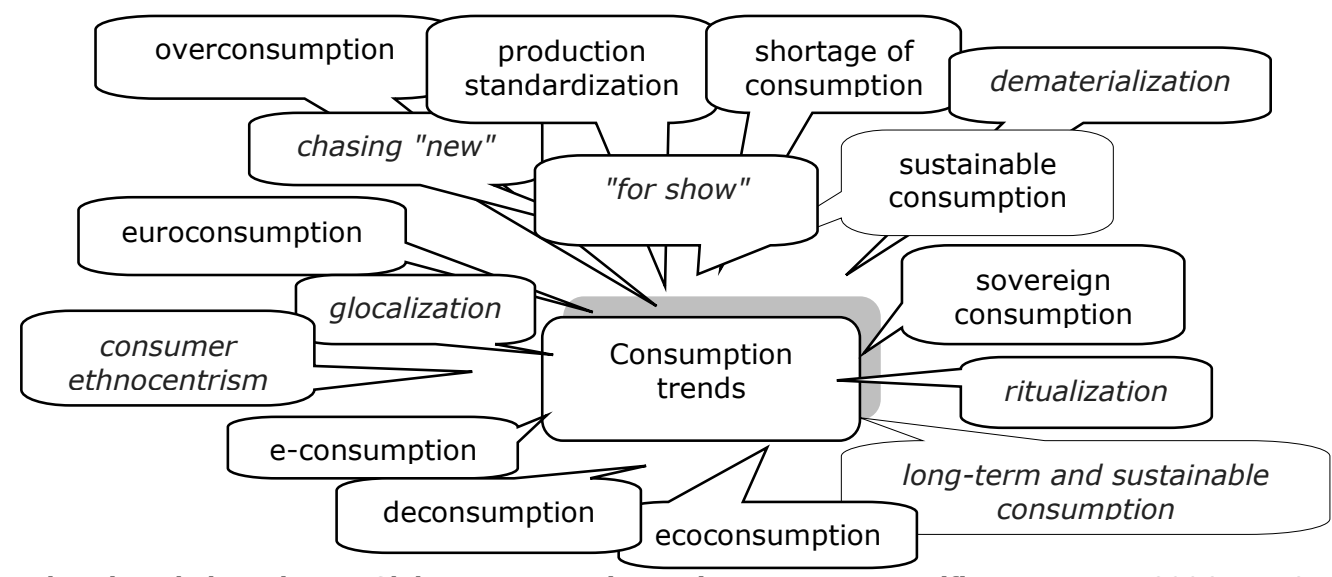

Source: authors' study based on T. Slaby, Konsumpcja. Eseje statystyczne, Difin, Warszawa 2006, p. 16.

Fig. 1. New trends in consumption

The contemporary society has great importance in the evolution of consumption and highly values the state of ownership. The previously recognized cultural values have been replaced by the pursuit of satisfaction through consumption, where, sooner than necessary, there is a desire to satisfy it (Konsument i konsumpcja..., 2006). As a result, consumerism is created as an excessive consumption of foods and services. The increase of society's incomes leads to the increase in consumption, and, thus, the need for continuous production. This entails the demand increase for natural resources, and after consumption, the collection of waste increase, contributing to environmental degradation. Unsustainable consumption of dairy products means improper use and wastage of valuable ingredients. Irrational use of these, in addition to quantitative losses, causes excessive consumption of natural resources. The condition for stopping the negative effects of consumerism must be changes which create consumption based on principles convergent with the idea of sustainable development, based on culture and ecological awareness. In the world of globalism, various organizations take initiatives of this nature, creating new trends that include greening and sustainable consumption.

Sustainable consumption by OECD definition means the use of goods and related products which respond to basic needs and bring a better quality of life, while minimising the use of natural 
resources and toxic materials as well as the emissions of waste and pollutants over the life cycle, so as not to jeopardise the needs of future generations (Os/o Rountable..., 1994; Jolly A., 2003).

As regards the food market, including the milk market, which is focused on sustainable development, nutritional and social objectives related to behaviour promotion are crucial (Sznajder M., 2008). Consumption of dairy products is generally widespread and massive, and consumers' decisions are increasingly influenced by current sales conditions.

\section{Marketing activities}

In the $21^{\text {st }}$ century, enterprises and consumers operate in an ever-changing enviroment, which requires flexibility and unprecedented adaptation from entrepreneurs. In the era of globalism, consumers' behaviour, needs and expectations are different than those which were known by the marketing specialist several or dozen years ago.

Maintaining a competitive advantage over market competitors in the conditions of a hypercompetitive enviroment requires from the entrepreneurs constant monitoring of new trends, changes in consumption patterns, in consumer behaviour and suitable adaptation of their marketing strategies.

Having knowledge about changes in behaviour may be a competitive advantage in today's world, and the emerging new consumer trends force entrepreneurs to react through the following activities (Husak Z., 2013):

- focus on deepening the knowledge about your clients;

- involvement in various forms of dialogue with the target market - dialogue with consumers;

- personalization of the chain value - adaptation to the needs and expectations of specific consumers, ranging from product features to flexible delivery dates and convenient payment dates;

- shaping positive experiences at every stage of value creation;

- cooperation with clients and consumers as business partners - implementation of crowdsourcing projects, joint creation of new, innovative products or services.

The dairy market is increasingly influenced by the current sales conditions that result from dynamic changes in the offers of producers combined with high availability of products. To a large extent, they generate promotional sales activities (Stefańska M., 2009). According to Krajewski, the choice of dairy products and purchasing decisions are more and more often determined by the place and terms of purchase. Advertising usually gives a reason to buy and the sale's promotion offers an incentive in the place where it is offered. Everything that the consumer perceives and senses at the place of purchase has an impact on his behavior and purchasing decisions which are made in the conditions of modern trade (Krajewski K., 2011). In this situation, entrepreneurs producers and traders show greater interest in marketing activities in the field of sales promotion. Striving for the high loyalty of consumers, entrepreneurs implement promotional strategies and marketing activities aimed directly at the store's clients and traders at the point of sales - POS (Światkowska M., 2011).

In the Polish dairy market reality, entrepreneurs apply marketing activities in the promotion of two separate product categories: modern (yoghurt, granular cheese, UHT milk and ripening cheese) and traditional (curd, butter).

The directions of promotional activities for modern products, whose sales are intensively supported by all promotion instruments, require the use of a "push" strategy and a higher level of 
financing, which ultimately translates into a higher product price. For traditional products, on the other hand, the level of promotional support is relatively lower and refers primarily to price promotions, which also means lower purchase prices for consumers.

In marketing strategies that makeuseof a balanced approach, dairy market entities should take into account the overall concept of implementing sustainable patterns of consumption and food production - all aspects and stages of product life, from production to consumption and the use of appropriate promotion instruments. Balanced nutritional value, diet and lifestyle are issues that the entrepreneur should consider in creating their market messages.

\section{Research results and discussion}

Many factors affect the consumption of milk. The authors, basing on available reliable data published by Central Statistical Office, EUROSTAT, Institute of Agricultural Economics and Food Economy and Agricultural Market Agency, identified the determinants relevant to the milk market in Poland.

The data set for the analysis concerned issues related to, inter alia, purchase of milk, the volume of milk products production, the volume of consumption, the demographic situation, the price of unprocessed and processed agricultural products. The whole set the variables identified by the authors included 46 items. However, the analysis covered five factors.

The research period adopted for the analysis is from 2010 to 2016. The years adopted for the analysis is a period of dynamic changes that took place in politics, economy and demographics in Poland. These changes were also reflected in agriculture as well as production, purchase and processing of milk.

From the set of all determinants (46 factors), only those that were characterized by a high level of variation were subject to further analysis. As a result, a list of determinants was obtained (Table 1).

\section{Determinants}

Table 1

\begin{tabular}{|l|c|l|}
\hline No & Variable & \multicolumn{1}{c|}{ Endogenous Determinant } \\
\hline $\mathbf{1 .}$ & $\mathbf{Y}$ & Milk consumption in litres per capita \\
\hline 1. & $\mathbf{X 1}$ & $\begin{array}{l}\text { Average retail prices of consumer goods and services - cow's milk with a fat content of 3- } \\
\text { 3.5\%, sterilized - for PLN 1/PLN }\end{array}$ \\
\hline 2. & $\mathbf{X 2}$ & Average retail prices of consumer goods and services - Fruit yogurt - for 150g / PLN \\
\hline 3. & $\mathbf{X 3}$ & Average retail prices of consumer goods and services - semi-fat curd cheese - for $1 \mathrm{~kg} /$ PLN \\
\hline 4. & $\mathbf{X 4}$ & $\begin{array}{l}\text { Average retail prices of consumer goods and services - fresh butter with a fat content of } \\
\text { approx. 82.5 \% - for 200g / PLN }\end{array}$ \\
\hline 5. & $\mathbf{X 5}$ & Consumption of butter in kilograms per capita \\
\hline
\end{tabular}

Exogenous determinants analyzed in the period from 2010 to 2016 showed an upward trend $(\mathrm{X} 1, \mathrm{X} 2, \mathrm{X} 3, \mathrm{X} 5)$ with the exception of the average retail prices of fresh butter goods and services with a fat content of approximately $82.5 \%$ (Zeliaś A, Pawełek B, Wanat S, 2003). On the other hand, the endogenous variable in 2012 and 2014 recorded declines in value, comparing yearon-year data (Table 2). 
Trends of exogenous determinants

Table 2

\begin{tabular}{|l|c|l|c|c|}
\hline No & Variable & \multicolumn{1}{|c|}{ Question } & $\begin{array}{c}\text { Trend line } \\
\text { pattern }\end{array}$ & Slope \\
\hline 1. & $\mathbf{X 1}$ & $\begin{array}{l}\text { Average retail prices of consumer goods and services - cow's } \\
\text { milk with a fat content of 3-3.5 \%, sterilized - for PLN 1 / PLN }\end{array}$ & $\begin{array}{c}y=0.0207 x+ \\
2.7186\end{array}$ & positive \\
\hline 2. & $\mathbf{X 2}$ & $\begin{array}{l}\text { Average retail prices of consumer goods and services - fruit } \\
\text { yogurt - for 150g / PLN }\end{array}$ & $\begin{array}{c}y=0.0204 x+ \\
1.1057\end{array}$ & positive \\
\hline 3. & $\mathbf{X 3}$ & $\begin{array}{l}\text { Average retail prices of consumer goods and services - semi-fat } \\
\text { curd cheese - for 1kg / PLN }\end{array}$ & $\begin{array}{c}y=0.2057 x+ \\
12.066\end{array}$ & positive \\
\hline 4. & $\mathbf{X 4}$ & $\begin{array}{l}\text { Average retail prices of consumer goods and services - fresh } \\
\text { butter with a fat content of approx. 82.5 \% - for 200g / PLN }\end{array}$ & $\begin{array}{c}\mathrm{y}=-0.0146 \mathrm{x} \\
+4.3814\end{array}$ & negative \\
\hline $\mathbf{5 .}$ & $\mathbf{X 5}$ & Consumption of butter in kilograms per capita & $\begin{array}{c}\mathrm{y}=0.0821 \mathrm{x}+ \\
3.9429\end{array}$ & positive \\
\hline
\end{tabular}

Source: author's calculations

Then, on the basis of the value of endogenous variable and potential exogenous variables, the correlation vector and the correlation coefficient matrix were determined. These values were then used to select variables for the model (Kowalik K., 2014). The number of possible combinations for exogenous variables was determined using the Hellwig method. Five possible combinations were obtained from five variables, which were analyzed by determining the individual information capacity for each of them (Sobczak M., 2013).

Formulae - The information capacity - The Hellwig Method

$$
H_{1}=\frac{r_{j}^{*}}{\Sigma\left|r_{\text {gq }}\right|}
$$

Where:

$I$ - the number of the combintion;

$r_{j}$ - linear correlation coefficient between endogenous variable and the $j$-th exogenous variable

$r_{i j}$ - linear correlation coefficient between the i-th endogenous variable and the $j$-th exogenous variable occurring in a given combination

The values of individual capacity of information for exogenous variables are included in Table 3. 
Individual information capacities

Table 3

\begin{tabular}{|c|c|c|c|c|c|c|c|}
\hline No & Variable & Combination & Capacity & No & Variable & Combination & Capacity \\
\hline 1. & H1 & $\mathrm{X} 1$ & 0.1137 & 16. & H16 & $\times 1 \times 2 \times 3$ & 0.4169 \\
\hline 2. & $\mathrm{H} 2$ & $x 2$ & 0.3189 & 17. & H17 & $\times 1 \times 2 \times 4$ & 0.0876 \\
\hline 3. & H3 & $\mathrm{x} 3$ & 0.6749 & 18. & H18 & $\times 1 \times 2 \times 5$ & 0.5796 \\
\hline 4. & H4 & $x 4$ & 0.0374 & 19. & H19 & $\times 1 \times 3 \times 4$ & 0.4088 \\
\hline 5. & H5 & $\times 5$ & 0.5373 & 20. & $\mathrm{H} 20$ & $\times 1 \times 3 \times 5$ & 0.7439 \\
\hline 6. & H6 & $\mathrm{X} 1 \mathrm{X} 2$ & 0.2386 & 21. & H21 & $\mathrm{X} 1 \mathrm{X} 4 \times 5$ & 0.4083 \\
\hline 7. & H7 & $\times 1 \times 3$ & 0.4488 & 22. & H22 & $\times 2 \times 3 \times 4$ & 0.4807 \\
\hline 8. & H8 & $\times 1 X 4$ & 0.0967 & 23. & $\mathrm{H} 23$ & $\times 2 \times 3 \times 5$ & 0.8363 \\
\hline 9. & H9 & $\times 1 \times 5$ & 0.5970 & 24. & $\mathrm{H} 24$ & $\times 2 \times 4 \times 5$ & 0.5393 \\
\hline 10. & H10 & $\times 2 \times 3$ & 0.5253 & 25. & H25 & $\times 3 \times 4 \times 5$ & 0.6923 \\
\hline 11. & H11 & $\times 2 \times 4$ & 0.2676 & 26. & H26 & $X 1 \times 2 \times 3 \times 4$ & 0.3908 \\
\hline 12. & H12 & $\times 2 \times 5$ & 0.8112 & 27. & $\mathrm{H} 27$ & $\times 1 \times 2 \times 3 \times 5$ & 0.7341 \\
\hline 13. & H13 & $\times 3 \times 4$ & 0.5772 & 28. & $\mathrm{H} 28$ & $\times 1 \times 2 \times 4 \times 5$ & 0.4873 \\
\hline 14. & H14 & $\times 3 \times 5$ & 0.8803 & 29. & H29 & X1X3X4X5 & 0.5909 \\
\hline 15. & H15 & $\times 4 \times 5$ & 0.3312 & 30. & H30 & $\times 2 \times 3 \times 4 \times 5$ & 0.6702 \\
\hline ---- & ------- & -----.---.-- & --------- & 31. & H31 & $\times 1 \times 2 \times 3 \times 4 \times 5$ & 0.5945 \\
\hline
\end{tabular}

Source: author's calculations

From the set of all combinations, the one to be chosen should be the one for which the information capacity has the highest value. Among the analyzed exogenous variables, this combination concerns the $\times 3 \times 5$ dependencies, occurring between the average retail prices of consumer goods and services - semi-fat curd cheese - for $1 \mathrm{~kg} / \mathrm{PLN}$ and butter consumption in kilograms per capita.

Based on these variables, an econometric model was created using the classic method of least squares. As a result of the calculations, the following model was obtained:

$$
\hat{Y}=\begin{aligned}
& 14.36 x_{3}+22.02 x_{5}-76.37 \\
& ( \pm 4.16) \quad( \pm 8.22) \quad( \pm 51.86)
\end{aligned}
$$

On the basis of the model, one can assess consumer purchasing behaviour according to the exogenous variable, which is the level of per capita milk consumption. Consumption of milk per person is primarily related to the average retail prices of goods and services of the semi-fat curd cheese and the amount of butter consumed in kilograms per person.

The fit of the model (coefficient of determinacy) reached the value of 0.88 , which proves that only in $12 \%$ percent the model does not adhere to reality and the standard deviation of residues was 4.66, which proves that empirical values of milk consumption per person differ, on average, from the theoretical values resulting from the model by 4.66 litres per person.

\section{Conclusions}

1) The analysis of the value of correlation coefficients showed that consumers have positive purchasing preferences regarding milk consumption in Poland, which is exemplified by the increase in milk consumption in the analyzed period. In 2010, the per capita milk consumption was 189 litres, to reach 219 litres per person in 2016.

2) In the Polish dairy market reality, entrepreneurs costomize the product offer to the needs and expectations of the modern consumer and use more and more modern forms of sales 
promotion, which at the same time contributes to the consumption growth of specific dairy products.

3) Marketing activities undertaken by entrepreneurs operating on the milk market contributed primarily to the consumption of butter and semi-skimming curd - traditional products for which the level of promotional support is relatively lower, and thus prices are also lower. However, despite higher promotional support and marketing campaigns, the consumption of yogurt, fresh butter and sterilized cow's milk with a fat content of 3-3.5\% had no impact on milk consumption in Poland.

4) In the era of globalism, a healthy lifestyle and more and more heterogeneous needs of the modern consumer will play an increasingly important role and will affect the level of consumption of individual product groups. Currently available data do not include detailed breakdowns for the consumption of "healthy" products, which made the analysis impossible.

\section{Bibliography}

1. Baudrillard, J. (2006). Spoleczenstwo konsumpcyjne, jego mity i struktury. Sic!, Warszawa, p. 63.

2. Husak, Z. (2013). Zagadnienie gromadzenia danych o uzytkownikach portali internetowych na potrzeby profilowania marketingowego, w: Wspolczesne uwarunkowania promocji i reklamy, red. A.J. Kukula, Difin, Warszawa, p. 91.

3. Jolly, A. (2003). OECD Economies and the World Today: Trends, Prospects, and OECD Statistics, Kogan Page Publishers, p. 120.

4. Konsument i konsumpcja we wspótczesnej gospodarce, M.Janos-Kreslo, B. Mroz (red.), SGH,Warszawa 2006, s 41.

5. Kowalik, K. (2014). On Implementation of the Methot of Capacity of Information Bearers (the Hellwig method) in spredsheets, in: Banek, T. and Kozlowski, E. ed.: Probability in Action. Politechnika Lubelska, pp. 31-40.

6. Krajewski, K. (2011). Wybrane czynniki okreslajace decyzje zakupowe nabywcow produktow mleczarskich a warunki sprzedazy. Zeszyty Naukowe Uniwersytetu Ekonomicznego w Poznaniu., No 175, pp. 188-195.

7. Mroz, B. (2009). Consumo egro sum? Rola konsumpcjonizmu we wspolczesnych spoleczenstwach, [w:] B. Mroz (red.), Oblicza konsumpcjonizmu. SGH, Warszawa, p. 8.

8. Oslo Rountable on Sustainable Production and Consumption, 1994, http://www.iisd.ca/consume/oslo004.html\#top Access:10.01.2018.

9. Ryszawska, B. (2013). Zielona gospodarka - teoretyczne podstawy koncepcji i pomiar jej wdrazania w Unii Europejskiej, Wydawnictwo Uniwersytetu Ekonomicznego we Wroclawiu, Wroclaw.

10.Słaby, T. (2006). Konsumpcja. Eseje statystyczne. Difin, Warszawa, p. 17.

11.Sobczyk, M. (2013). Ekonometria. Wydawnictwo C.H.Beck, Warszawa, pp. 17-24.

12. Stefańska, M. (2009). Postawy konsumentow wobec wybranych srodkow aktywizacji sprzedazy. Zeszyty Naukowe Uniwersytetu. Szczecinskiego No 559, Ekonomiczne Problemy Usług No 42, Wydawnictwo Naukowe Uniwersytetu Szczecinskiego, Szczecin, pp. 360-368.

13. Swiatkowska, M. (2011). Postawy polskich konsumentow wobec wybranych instrumentow promocji. Zeszyty Naukowe Uniwersytetu Ekonomicznego w Poznaniu No 208, pp. 266-277.

14. Sznajder, M. (2008). The Concept of Sustainable Food Chain (Case Study-The Dairy Food Chain). J. Agribus. Rural Dev., No 2(8), pp. 155-163.

15. Veblen, T. (2008). Teoria klasy prozniaczej. Muza, Warszawa, p. 65.

16. Zeliaś, A., Pawełek, B., Wanat, S. (2003). Prognozowanie ekonomiczne. Wydawnictwo Naukowe PWN, Warszawa, pp. 70-75. 